\title{
KONTROVERSI PEMIKIRAN ANTARA IMAM MALIK DENGAN IMAM SYAFI'I TENTANG MASLAHAH MURSALAH SEBAGAI SUMBER HUKUM
}

\author{
Taufiqur Rohman \\ Sekolah Tinggi Agama Islam Walisembilan (SETIA WS) \\ E-mail : azharqudsiyyah@yahoo.co.id
}

\begin{abstract}
This article discusses about argument of maslahah mursalah as a source of law. The focus of the study in this paper is a controversial idea between Imam Malik and Imam Shafi'i about maslahah mursalah as a source of law. Controversy thinking between both of them as a source of law. First, Imam Malik used maslahah mursalah as a source of law, but Imam Malik stressed the establishment of the law by taking the benefit and using the ratio, it must not controvert with the rule of law that has been set by nash or ijma'. If there is a controversy then it must precede nash than maslahat. Secondly, Imam Shafi'i did not use maslahah mursalah as a source of law because it did not have a definite standard of nash and qiyas, while Imam Shafi'i's establishment is all of law must be based on nash as qiyas. Imam Shafi' did not mention this method in his book, al-Risalah. This controversy caused by the absence of a special argumentation that declare about maslahah accepted by Syar'i either directly or indirectly.
\end{abstract}

Key Word: Controversy, Imam Malik, Imam Syafi'i, maslahah mursalah, the source of law

\begin{abstract}
ABSTRAK
Artikel ini mendiskusikan kehujjahan maslahah mursalah sebagai sumber hukum. Fokus kajian dalam tulisan ini adalah kontroversi pemikiran Imam Malik dengan Imam Syafi'i tentang maslahah mursalah sebagai sumber hukum. Kontroversi pemikiran antara keduanya tentang kehujjahan maslahah mursalah sebagai sumber hukum. Pertama, Imam Malik menggunakan maslahah mursalah sebagai sumber hukum, tetapi Imam
\end{abstract}


Malik menekankan bahwa pembentukan hukum dengan mengambil kemaslahatan yaitu dengan menggunakan rasio tidak boleh bertentangan dengan tata hukum yang telah ditetapkan nash atau ijma'. Apabila terjadi pertentangan maka wajib mendahulukan nash dibandingkan maslahat. Kedua, Imam Syafi'i tidak menggunakan maslahah mursalah sebagai sumber hukum karena mashlahah mursalah tidak memiliki standar yang pasti dari nash maupun qiyas, sedangkan pendirian Imam Syafi'i semua hukum haruslah didasarkan nash atau disandarkan pada nash sebagaimana qiyas. Imam Syafi'i sendiri tidak menyinggung metode ini dalam kitabnya al-Risalah. Adanya kontroversi ini karena tidak adanya dalil khusus yang menyatakan diterimanya maslahah oleh Syar'i baik secara langsung maupun tidak.

Kata Kunci: Imam Malik; Imam Syafi'i; Kontroversi; Maslahah Mursalah; Sumber Hukum

\section{A. Pendahuluan}

Salah satu konsep penting dan fundamental yang menjadi pokok bahasan hukum Islam adalah konsep kepentingan umum (maslahah, public interest) (Rofiq, 2012: 38). Hal ini karena kepentingan umum bersifat dinamis dan fleksibel (Yasid, 2012: 27). Artinya, perkembangan kepentingan umum ini seiring dengan perkembangan zaman. Konsekuensinya, bisa jadi yang dianggap kepentingan umum pada waktu yang lalu belum tentu dianggap sebagai kepentingan umum (maslahah) pada masa sekarang (Abdullah, 2015: 9-10). Maslahah termasuk di dalamnya mashlahah mursalah merupakan satu tema yang sangat populer dalam kajian mengenai hukum Islam karena maslahah merupakan tujuan syara' dari ditetapkannya hukum Islam.

Konsep maslahah tumbuh berkembang sejalan dengan berkembangnya hukum Islam. Secara aplikatif keberadaannya telah ada sejak periode awal Islam (Al-Kafrawi, 2002: 503). Maslahah atau maqashid as-syari'ah seperti halnya ilmu-ilmu syari'ah yang lain, membutuhkan proses waktu yang sangat panjang untuk menjadi sebuah ilmu yang mandiri. Karena sebelumnya merupakan bagian dari Ushul fiqh, (Al-Asyqâr, 1998: 7) ada beberapa alasan maqashid as-syariah menjadi ilmu yang mandiri, antara lain: Pertama, Maqashid as-syariah selalau berada dibalik nash-nash al-Qur'an, Sunnah dan fatwa sahabat. Kedua, Qiyas sudah lama menjadi bahan perdebatan dan qiyas selalu didasarkan pada illat yang sesuai 
sebagai dasar hukum maupun sebagai penetapan illat hukum, maka ketika membicarakan qiyas maka otomatis juga membicarakan maqashid assyariah. Ketiga, keberadaan maqashid as-syariah sebagai petunjuk hikmah ditetapkan suatu hukum dalam masalah-masalah fiqh (Imam Yahya, 2013: 94-95).

Menurut Husain Hâmid Hisân, Adanya kontoversi pemikiran di kalangan ulama klasik termasuk Imam Malik dan Imam Syafi'i mengenai penggunanan maslahah mursalah sebagai sumber hukum adalah karena tidak adanya dalil khusus yang menyatakan diterimanya maslahah itu oleh Syar'i baik secara langsung maupun tidak langsung karena menurut jumhur ulama' maslahah itu bisa diaplikasikan kalau ada dukungan dari Syar'i, meskipun secara tidak langsung. Digunakannya maslahah itu bukan karena maslahah, tetapi karena adanya dalil syar'i yang mendukungnya (Hisân, 1971:13-14).

Kehujjahan Maslahah sebagai sumber hukum terbagi menjadi tiga yaitu; yang dibenarkan oleh syara' yaitu Maslahah Mu'tabarah, ditolak oleh syara' yaitu Maslahah Mulghah dan yang diperselisihkan yaitu Maslahah Mursalah, jumhur Ulama' telah berkonsensus, maslahah Mu'tabarah diterima sebagai hujjah dan Maslahah Mulghah ditolak sebagai hujjah. Sedangkan maslahah Mursalah diperselisihkan karena tidak ada dalil yang membenarkan maupun yang melarangnya (Al-Syâtibi: 9).

\section{B. Pembahasan}

\section{Maslahah Mursalah dalam Prespektif Hukum Islam}

Ada beberapa rumusan difinisi oleh para pakar Ushul Fiqh tentang maslahah mursalah (Zein, 2005:148-149), tetapi masing-masing mempunyai kesamaan dan berdekatan pengertiannya, antara lain:

Dari kalangan ulama Syafi'i, Al-Ghazali (w. 505 H), merumuskan maslahah mursalah dengan maslahah yang tidak ada bukti baginya dari syara' dalam bentuk nash tertentu baik yang membatalkannya maupun tidak ada perhatian baginya(Al-Gazâli, 1997:481).

Dari kalangan ulama Zaidiyyah, Al-Syaukani merumuskannya dengan maslahah yang tidak diketahui apakah Syari menolaknya atau memperhitungkannya (Asy-Syaukānî, 1999: 990-994) 
Dari kalangan ulama Hanbali, Ibnu Qudamah yaitu; maslahat yang tidak ada bukti petunjuk tertentu yang membatalkannya dan tidak pula memperhatikannya.

Dari kalangan ulama Hanafi, Yusuf Ahmad Muhammad al-Badawi, yaitu: ketika seorang mujtahid melihat bahwa suatu pekerjaan dapat mendatangkan manfaat yang lebih diprioritaskan, tetapi dalam Syara' tidak ada dalil yang menolaknya (Al-Badawi, 2000: 61).

Yusuf Hamid al-A'lim memberikan rumusan: maslahah yang tidak ada petunjuk syara' tidak untuk membatalkannya, juga tidak untuk memperhatikannya (Al-A'lim, 1994:124). Abd al-Wahhâb Khallâf, memberikan rumusan: maslahah yang tidak ada dalil syara' yang datang untuk mengakuinya ataupun menolaknya(Khallâf, 1972:173).

Jalâl al-Dîn 'Abd al-Rahmân,yaitu: maslahah yang selaras dengan tujuan Syar'i (Pembuat hukum) dan tidak ada petunjuk tertentu yang membuktikan tentang pengakuannya atau penolaknnya (Al-Rahmân, 1983: 27). Muhammad Abu Zahrâh, yaitu: maslahah yang selaras dengan tujuan syari'at Islam dan tidak ada petunjuk tertentu yang membuktikan tentang pengakuannya atau penolaknya(Zahrâh,1958:280).

Dari berbagai rumusan difinisi marsalah mursalah diatas, dapat diambil konklusi sebagai berikut: Pertama, marsalah mursalah adalah sesuatu yang baik menurut akal sehat dengan alasan bahwa untuk mewujudkan kebaikan atau menghindarkan keburukan bagi manusia. Kedua, segala sesuatu yang baik menurut akal yang sehat dan selaras dengan tujuan syara' dalam menetapkan hukum.Ketiga, segala sesuatu yang baik menurut akal yang sehat dan selaras dengan tujuan syara' tersebut tidak ada petunjuk dari syara' secara khusus yang menolaknya, juga tidak ada petunjuk syara' yang mengakuinya.

Sedangkan landasan hukum maslahah mursalahdari Al-Qur'an maupun Hadits, sebagai berikut:

"Hai manusia, sesungguhnya telah datang kepadamu pelajaran dari Tuhanmu dan penyembuh bagi penyakit-penyakit (yang berada) dalam dada dan petunjuk serta rahmat bagi orang-orang yang beriman". (QS. Yunus: 57)

"Katakanlah: "Dengan karunia Allah dan rahmat-Nya, hendaklah dengan itu mereka bergembira. karunia Allah dan rahmat-Nya itu adalah lebih baik dari apa yang mereka kumpulkan". (QS.Yunus: 58) 
"Mereka bertanya kepadamu tentang anak yatim, katakalah:"Mengurus urusan mereka secara patut adalah baik, dan jika kamu bergaul dengan mereka, maka mereka adalah saudaramu dan Allah mengetahui siapa yang membuat kerusakan dari yangmengadakan perbaikan. Dan jikalau Allah menghendaki, niscaya dia dapat mendatangkan kesulitan kepadamu. Sesungguhnya Allah Maha Perkasa lagi Maha Bijaksana". (QS. AlBaqarah:220) (Depag, 1984: 659).

Sedangkan sumber hukum maslahah mursalah yang diambil dari Hadits yang diriwayatkan oleh Ibn Majjah, Rasulullah SAW bersabda:

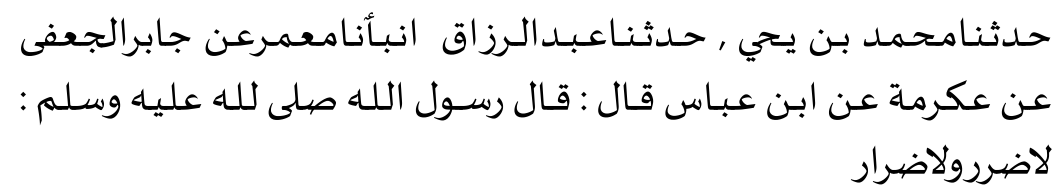

"Muhammad Ibn Yahya bercerita kepada kami, bahwa Abdur Razzaq bercerita kepada kita, dari Jabir al-Jufyyi dari Ikrimah, dari Ibn Abbas: Rasulullah SAW bersabda, "tidak boleh membuat mazdarat (bahaya) pada dirinya dan tidak boleh pula membuat mazdarat pada orang lain". (HR. Ibn Majjah) (Al-Qazwini: 784).

Maka atas dasar dari Al-Qur'an maupun al-Sunnah di atas, 'Izz alDîn ibn 'Abd al-Salâm, menyatakan bahwa maslahah dalam hukum Islam hanya dikembalikan kepada dua kaidah induk saja, yaitu: (1) Kaidah mewujudkan kemaslahatan (jalbul masalih) dan (2) kaidah menghindari kerusakan (dar'ul mafasid) (Al-Salâm, 1994: 31) Pendapat yang sama juga dikemukakan Al-Gazâli dalam kitabnya al-Mustasfa min'Ilm al-Usûl (AlGazâli,1997: 416-417)

\section{Kontroversi Maslahah mursalah sebagai sumber hukum antara Pemikiran Imam Malik dengan Imam Syafi'i}

\section{a. Pemikiran Imam Malik}

Abû Ishâq Ibrâhîm al-Syâtibi,Imam Malik beserta penganut madzhab Maliki adalah kelompok yang secara jelas menggunakan maslahah mursalah (Al-Amidi, 1967: 155) sebagai metode ijtihad (AlSyâtibi: 6). penjelasan yang sama juga dikemukakan Abdul Karim Zaidan, (Zaidan,1958: 147) dengan alasan yang cukup rasional, antara lain:

Pertama, para sahabat Nabi banyak yang menggunakan maslahah mursalah sebagai dalil hukum (Huda, 2012: 16), seperti pengkodifikasian 
Alquran oleh Abu Bakar ash-Shiddiq, penunjukkan Umar bin Khattab oleh Abu Bakar ash-Shiddiq sebagai khalifah sepeninggalnya, pemisahan dan pembagian harta pejabat dengan wilayah kekuasaannya oleh Umar bin Khattab (Supriyadi, 2006:90), kebijakan Ali bin Abi Thalib tentang tadhmin al-shana'i yaitu kewajiban pembuat barang untuk mengganti rugi kerusakan atau kekeliruan barang yang dipesan (Al-Syâtibi:119), para sahabat menetapkan hukuman mati terhadap satu kelompok yang melekakuakan pembunuhan terhadap satu orang ketika mereka melakukannya secara bersama-sama (Al-Syâtibi:125). Ijtihad Mu’adz ibn Jabal ketika tidak menemukan dalil dari Al-Qur'an dan hadis (Ma'mur, 2015: 101).

Kedua, menggunakan maslahah mursalah sama halnya mengaplikasikan tujuan syar'i (maqashid syariah), sebaliknya membiarkannya berarti membuang maqashid syari'ah, oleh karenanya maslahah adalah sumber hukum pokok (ashl) yang berdiri sendiri serta sumber hukum ini tidak keluar dari sumber hukum pokok (ashl), bahkan terjadi sinkronisasi antara maslahahdan maqashid syariah (Zahrah:182).

Ketiga, kontroversi maslahah sebagai sumber hukum bersifat kondisional, karena mempunyai dampak kemandulan pada prinsip dasar hukum Islam yang telah disepakati bersama (ijma'), sehingga mukallaf akan mengalami kesulitan dan kesempitan, padahal Allah Swt tidak menghendaki akan hal itu (Q.S. Al-Baqoroh:185 dan Q.S. al Hajj:76).

Imam Malik memberikan kriteria tersendiri dalam maslahah mursalah sebagai sumber hukum, antara lain:Pertama, maslahah tersebut harus bersifat reasonable dan relevan terhadap kasus hukum yang telah ditetapkan (Al-Syâtibi:129). Kedua, maslahah tersebut dijadikan dasar untuk memelihara sesuatu yang dharuri dan menghilangkan kesulitan (raf'ul haraj), dengan cara menghilangkan kepayahan (masyaqat) dan bahaya (madharat) (Al-Syâtibi:133). Ketiga, maslahah tersebut harus sesuai dengan maqashid syariah, dan tidak bertentangan dengan dalil syara' yang qat'i. (Rokhmadi, 2012: 163)

Selain itu, Imam Malik juga memberikan prinsip-prinsip yang bersifat universal dalam menggunakan maslahah mursalah (Zuhaili: 8586.), antara lain: Pertama, berlakunya dugaan kuat dalam hukum, artinya menegakkan kuat kepada sesuatu dapat dijadikan sebagai sesuatu pada 
realitasnya, seperti berbaurnya antara lawan jenis yang bukan mahramnya, larangan ini mengandung unsur kecuriagaan yang kuat untuk berbuat zina, sehingga kecurigaan itu mengandung hukum tersendiri, Imam Malik menjadikan prinsip ini sebagai maslahah universal (Zuhaili: 85). Kedua, kewajiban mendahulukan maslahah secara umum daripada kemaslahatan secara pribadi (Al-Syalabi, 2000 M: 321). Ketiga, keabsahan menolak bahaya yang paling berat diantara dua bahaya (emergency), contohnya seperti perintah berjihad, meskipun efek sampingnya (madharat) beresiko kehilangan nyawa seseorang, tetapi perintah ini untuk mencegah bahaya musuh yang menyerang untuk menjaga agama dan negara, sebab eksistensi agama dan negara jauh lebih besar bila dibandingkan dengan nyawa seseorang (Zuhaili: 86). Keempat, kewajiban memelihara jiwa, seperti larangan membunuh seseorang, penegakan hukum dan peradilan dan sebagainya (Zuhaili: 87).

\section{b. Pemikiran Imam Syafi'i}

Sumber hukum Islam madzhab Syafi'i ada empat, yaitu: al-Qur'an, Sunnah, ijma’ dan Qiyas (Roibin, 2008:110). Imam Syafi'i (Al-Arabi, 1976: 303.), tidak menjadikan maslahah mursalah sebagai dalil hukum berijtihad. Karena Imam Syaf'i sendiri tidak menyinggungnya dalam karyanya alRisalah. Tetapi ada yang beranggapan bahwa maslahah mursalah berlaku di kalangan ulama' Syafi' iseperti al-Ghazali (Al-Subki, 1937: 91-92).

Pada prinsipnya Imam Syafíi selalu menggunakan dalil nash dalam memahami dan menetapkan hukum, baik secara langsung, yaitu alQur'an dan Sunnah atau tidak langsung, yaitu ijma' dan qiyas. Menurut Imam Syafi'i kemempuan seseorang tentang hukum syara' tergantung pemahamannya terhadap nash. Maka pemahaman terhadap dalil hukum syara' berarti pemahaman terhadap kaidah-kaidah bahasa Arab itu sendiri karena al-Qur'an dan Sunnah adalah teks yang menggunakan bahasa Arab (As-Syafi'i:142).

Dari pernyataan Imam Syafi'i diatas, maka dapat disimpulkan bahwa semakin seseorang memahami bahasa Arab dengan baik, maka semakin baik pula pemahamannya terhadap dalil dan hukum yang terkandung dalam dalil itu, dengan demikian mereka yang sebahasa dengan Nabi adalah mereka yang mempunyai kemampuan terbaik dalam memahami dalil. Bagi Imam Syafi'i urut-urutan sumber hukum Islam tidak 
boleh dibolak-balik, melainkan harus secara mutlak berurutan. Menurut Imam Syafi'i mashlahah mursalah tidak dapat diterima sebagai metode istinbat karena mashlahah mursalah itu tidak memiliki standar yang pasti dari nash maupun qiyas (Al-Gazâli, 1997: 286-287), sedangkan pendirian as-syafi'i semua hukum haruslah diberdasarkan nash atau di sandarkan pada nash sebagaimana qiyas (Abu Zahra, 1976: 303).

Menurut Imam Syafi'i seperti yang telah dinukilkan Husein Hamid Hasan, menyatakan bahwa maslahah mursalah sama seperti dalam pengertian qiyas, alasannya karena keduanya memiliki persamaan unsurunsur, syarat qiyas ada tiga, pertama, adanya peristiwa yang tidak ada nash hukumnya yang jelas, kedua, adanya hukum yang dinashkan oleh syar'i yang mungkin dihubungkan dengan peristiwa itu melalui pengertian ma'nawai, ketiga, peristiwa yang tidak ada nash hukumnya itu terkandung dalam kejadian yang mansus secara implisit. Ketiga sayarat qiyas ini menurutnya sejalan seperti maslahah mursalah atau maslahah mulaimah yaitu: pertama, peristiwa yang ingin diketahuinya melalui maslahah adalah peristiwa yang tidak ada nashnya secara jelas, seperti jaminan atau ganti rugi para pekerja apabila merusak barang yang dikerjakannya, kedua, ada hukum-hukum syariat yang dinashkan oleh syari' atas suatu peristiwa yang maknanya dapat ditemukan oleh para mujtahid, ketiga, peristiwa tidak ada nash tersebut memiliki makna yang sama dengan makna yang terkandung dalam peristiwa yang ada nashnya (Hasan, 1981: 324-325).

Dari penjelasan diatas dapat ditarik sebuah konklusi bahwa kontroversi pemikiran antara Imam Malik dengan Imam Syafi'i tentang maslahah mursalah sebagai sumber hukum. Pertama,Imam Malikmenggunakan maslahah mursalah sebagai sumber hukum, tetapi Imam Malikmenekankan bahwa pembentukan hukum dengan mengambil kemaslahatan yaitu dengan menggunakan rasio tidak boleh bertentangan dengan tata hukum atau dasar yang telah ditetapkan nash atau ijma'. Apabila terjadi pertentangan maka wajib mendahulukan nash dibandingkan maslahat. Kedua, Imam Syafi'i tidak menggunakan maslahah mursalah sebagai sumber hukum karena mashlahah mursalah tidak memiliki standar yang pasti dari nash maupun qiyas, sedangkan pendirian Imam Syafi'i semua hukum haruslah diberdasarkan nash atau di sandarkan pada nash sebagai mana qiyas. Imam Syaf'i sendiri juga tidak menyinggung metode 
maslahah mursalah dalam kitabnya al-Risalah. Menurutnya maslahah mursalah sama seperti dalam pengertian qiyas, alasannya karena keduanya memiliki persamaan unsur-unsur, syarat qiyas ada tiga, pertama, adanya peristiwa yang tidak ada nash hukumnya yang jelas, kedua, adanya hukum yang dinashkan oleh syar'i yang mungkin dihubungkan dengan peristiwa itu melalui pengertian ma'nawai, ketiga, peristiwa yang tidak ada nash hukumnya itu terkandung dalam kejadian yang mansus secara implisit. Ketiga sayarat qiyas ini menurutnya sejalan seperti maslahah mursalah.

\section{Persamaan dan perbedaan Pemikiran antara Imam Malik dan Imam Syafi'i dalam Maslahah Mursalah}

Dari uraian pandangan kedua tokoh diatas tentang maslahah mursalah sebagai sumber hukum, penulis menyimpulkan beberapa kesamaan keduanya, antara lain:Pertama, Mashlahah mursalah yang selama ini seakan diperdebatkan relevansinya sebagai metode pengambilan hukum antara Imam Malik dan Imam Syaf'i, pada dasarnya telah disepakati keduanya meskipun dengan menggunakan bahasa yang berbeda-beda. Tetapi dalam mengaplikasikan mashlahah mursalah ini tidak selayaknya dilakukan oleh seseorang yang tidak kompeten dalam ijtihad. Karena bagaimanapun juga mashlahah mursalah merupakan metode yang tidak dapat berdiri sendiri dan harus diiringi dengan maqashid syariah yang telah disepakati ulama'.Kedua, kedua tokoh ini sama-sama mengakui keberadaan maslahah atau kepentingan umum yang secara eksplisit maupun impilsit dalam nash al-Qur'an maupun Sunnah.

Adapun perbedaan pemikiran antara Imam Malik dengan Imam Syafi'i dalam maslahah mursalah sebagai sumber hukum ini, antara lain:Pertama, Imam Malik menggunakan maslahah mursalah sebagai sumber hukum, tetapi Imam Malik menekankan bahwa pembentukan hukum dengan mengambil kemaslahatan yaitu dengan menggunakan rasio tidak boleh bertentangan dengan tata hukum atau dasar yang telah ditetapkan nash atau ijma'. Apabila terjadi pertentangan maka wajib mendahulukan nash dibandingkan maslahat.Sedangkan Imam Syafi'i tidak menggunakan maslahah mursalah sebagai sumber hukum karena mashlahahmursalah itu tidak memiliki standar yang pasti dari nash maupun qiyas, karena pendirian Imam Syafi'i semua hukum haruslah diberdasarkan nash atau di sandarkan 
pada nash sebagai mana qiyas. Imam Syafi'i sendiri juga tidak menyinggung metode maslahah mursalah dalam kitabnya al-Risalah.Kedua, Imam Malik menyatakan alasan Allah mengutus seorang rasul adalah untuk membimbing umatnya kepada kemaslahatan. Sedangkan Imam Syaf'i adalah yang paling tegas menentang atas kehujjahan maslahah mursalah sebagai dalil hukum karena tidak memiliki standar yang pasti dari nash maupun qiyas, sedangkan pendirian Imam Syafi'i semua hukum haruslah diberdasarkan nash atau di sandarkan pada nash sebagaimana qiyas.Meski demikian hati-hatinya, Imam Syafi'i tidak berarti tidak beranjak sama sekali dari nash dan qiyas karena Imam Syafi'i pernah melakukan penelitian yang nyata-nyata tidak dijelaskan sama sekali oleh al-Qur'an, sebut saja misalnya ketika ia ditanya tentang batasan darah haid.Ketiga, Adanya kontroversi antara Imam Malik dengan Imam Syafi'i tentang maslahah mursalah sebagai sumber hukum ini karena tidak adanya dalil khusus yang menyatakan diterimanya maslahah itu oleh Syar'i baik secara langsung maupun tidak langsung karena maslahah itu bisa diaplikasikan kalau ada dukungan dari Syar'i, meskipun secara tidak langsung. Digunakannya maslahah itu bukan karena maslahah, tetapi karena adanya dalil syar'i yang mendukungnya.

\section{Implikasi kontroversi kehujjahan maslahah mursalah}

Hukum Islam tidak hanya dilihat sebagai alat untuk mengukur kebenaran ortodoksi, tetapi juga harus diartikan sebagai alat untuk membaca realitas sosial untuk kemudian mengambil sikap dan tindakan tertentu atas realitas sosial tersebut. Sehingga fiqh atau hukum Islam memiliki standar ganda, yaitu sebagai alat untuk mengukur realitas sosial dengan ideal-ideal syariat yang berujung pada hukum halal atau haram, boleh dan tidak boleh, dan sekaligus pada saat yang sama menjadi alat rekayasa sosial. Salah satu konsep penting dan fundamental yang menjadi pokok bahasan hukum Islam adalah konsep kepentingan umum (maslahah, public interest). Hal ini karena kepentingan umum bersifat dinamis dan fleksibel. Artinya, perkembangan kepentingan umum ini selalu berkembang seiring dengan perkembangan zaman. Konsekuensinya, bisa jadi yang dianggap kepentingan umum pada waktu yang lalu belum tentu dianggap sebagai kepentingan umum (maslahah) pada masa sekarang. Mashlahah mursalah yang selama ini seakan diperdebatkan relevansinya 
sebagai metode pengambilan hukum, pada dasarnya telah disepakati meskipun dengan menggunakan bahasa yang berbeda-beda. Tetapi dalam mengaplikasikan mashlahah mursalah ini tidak selayaknya dilakukan oleh seseorang yang tidak kompeten dalam ijtihad. Karena bagaimanapun juga mashlahah mursalah merupakan metode yang tidak dapat berdiri sendiri dan harus diiringi dengan maqashid syari'ah yang telah disepakati ulama'.

\section{Simpulan}

Maslahah Mursalah adalah salah satu dari bagian bentuk dari maslahah. Maslahah Mursalah, yaitu kemaslahatan yang tidak ditentukan nash tetapi juga tidak bertentangan, kepentingan yang ada di dalamnya seolah-olah diabaikan oleh syariah dan dibiarkan tanpa batasan maupun ketentuan.

Kehujjahan maslahah mursalah sebagai sumber hukum, terpecah menjadi dua kelompok, Pertama,menolak maslahah mursalah sebagai hujjah adalah Syafi'iyah, dengan alasan; maslahah mursalah sama seperti dalam pengertian qiyas, alasannya karena keduanya memiliki persamaan unsur-unsur, syarat qiyas ada tiga, pertama, adanya peristiwa yang tidak ada nash hukumnya yang jelas, kedua, adanya hukum yang dinashkan oleh syar'i yang mungkin dihubungkan dengan peristiwa itu melalui pengertian ma'nawai, ketiga, peristiwa yang tidak ada nash hukumnya itu terkandung dalam kejadian yang mansus secara implisit. Ketiga sayarat qiyas ini menurutnya sejalan seperti maslahah mursalah.Kedua, Malikiyah menerima maslahah mursalahsebagai hujjah syariahdan dijadikan metode pembentukan hukum mengenai kejadian yang hukumnya tidak ada dalam nash, ijma, qiyas atau istihsan. Tetapi tetap menggunakan aturan yang sangat ketat, antara lain: Pertama, maslahah tersebut haruslah yang nyata serta benar-benar membawa kepada kemanfaatan dan menolak kemadharatan bukan hanya sekedar berdasarkan prasangka. Kedua, kemaslahatan tersebut merupakan kemaslahatan yang umum, bukan kemaslahatan yang khusus baik untuk individu maupun kelompok tertentu, artinya kemaslahatan tersebut harus bisa dimanfaatkan atau menolak kemudaratan terhadap banyak orang pula. Ketiga, kemaslahatan tersebut tidak bertentangan dengan kemaslahatan yang terdapat dalam al-Qur'an dan Hadits baik secara zahir maupun batin. 


\section{BIBLIOGRAFI}

'Abd al-Salâm, 'Izz al-Dîn ibn, 1994, Juz ke-1,Qawâ'id al-Ahkâm fi Masâlih al-Anâm, Kairo:Maktabat al-Kulliyyât al-Azhariyyah.

'Atsyûr, Tâhir ibn, 2006, Maqâsid al-Syarî̀ah al-Islâmiyyah, Tunis: Dâr Suhnun, Kairo: Dar al-Salâm.

Abd al-Rahmân, Jalâl al-Dîn, 1983,'al-Masâlih al-Mursalah wa Makânatuhâ fi alTasyrî' al-Islâmiy, Kairo: Dâr al-Kitâb al-Jâmi'iy.

Abdullah,M. Amin, 2015, Fiqh dan kalam Sosial Era Kontemporer: perjumpaan Ulum al-din dan sains Modern Menuju Fresh Ijtihad, dalam buku Metodologi Fiqh Sosial, dari Qauli Menuju Manhaji, Pati: Fikih Sosial Institute Staimafa.

Al Qardhawi, Abdur Rohman Yusuf Abdullah, 2000, Nazariyyat Maqashid al-Syar'iyah baina Syaikhul Islam Ibnu Taiymiyyah wa Jumhur Ushulliyyin,

al- Syalabi, Musthafa, 2000, Ta'lilul ahkam fis Syariatil Islamiyyah, Kairo: Dar al-Basyir lis Syaqofah wal 'Ulum,

al-A'lim, Yusuf Hamid, 1994, Juz II,al-Maqasid al-Ammah lis Syariatil Islamiyya, Riyadh, Al-Ma;had al-Alamiy lil Fikr.

Al-Amidi, Sayf al-Din Abi al-Hasan 'Ali Ibn 1967, Juz ke-4, 'Ali Al-Ihkam fi Ushul al-Ahkam, Kairo: Muassasah al-Halabi.

Al-Asyqâr, 1998, al-Wadih fi Ushul Fiqh, Mesir: Dar as-salam.

al-Badawi, Yusuf Ahmad Muhammad, 2000, maqashid as-Syari'ah indā Ibnu Taymiyyah, Yordania; Dar an-Nafa'is.

al-Baqilani, Qodhi Abi Bakar Muhammad bin at-Tib , 1998, Taqrib wal Irsyad as-Shoghir, karya al-Baqilani, tahqiq Dr. Abdul Hamid bin Ali Abu Zanid, (Lebanon : Mu'assasah ar-Risalah.

al-Bashri al-Mu'tazili, Abi al-Husain Muhammad bin Ali bin al-Thiyb, 1964 M/1384 H, Kitab al-Mu'tamad fi Ushul al-fiqh, tahqiq Muhammad Hamidullah, Damaskus: Dar al-Sat al-Arabiyyah. 
al-Bugâ, Mustafa Dîb, t.th., Atsar al-Adillah al-Mukhtalaffîhâ au Masâdir alTasyrî' al-Taba'iyyah fi al-Fiqh al-Islâmiy, Damaskus: Dâr al-Imâm al-Bukhâri.

al-Bûti, Muhammad Saî̀ Ramadân, 2000, Dawâbit al-Maslahah fi alSyarî́ah alIslâmiyyah, Beirut: Mu’assasat al-Risâlah.

al-Gazâli, Abû Hâmid Muhammad,1997, Juz ke-1, al-Mustasfa min 'Ilm al-Usûl, tahqîq wa ta'lîq Muhammad Sulaimân al-Asyqar, Beirut: Mu'assasat al-Risâlah.

al-Gazâli, Abû Hâmid Muhammad,1997, Juz ke-1, al-Mustasfa min 'Ilm al-Usûl, tahqîq wa ta'lîq Muhammad Sulaimân al-Asyqar, Beirut: Mu'assasat al-Risâlah.

al-Ifrîqi, Jamâl al-Dîn Muhammad ibn Mukarram ibn Manzûr, 2003, Juz ke-2, Lisân al-'Arab, Riyad: Dâr 'Âlam al-Kutub.

al-Jauhari, Ismấîl ibn Hammâd,1956, al-Sihâh Tâj al-Lugah wa Sihâh al'Arabiyyah, Beirut: Dâr al-Ilm li al-Malâyîn.

al-Jauziyyah, Ibn al-Qayyim 2004 M, Juz ke-3, I'lâm al-Muwaqqi în 'an Rabb al-Âlamîn, Kairo: Dâr al-Hadîts.

al-Juwaini, Abul Ma'alli Abdul Malik bin Abdullah,1980, al-Burhan fi Ushulil Fiqh,tahqîq wa ta'lìq Prof.Dr. Abdul Adhim ad-Dib, Qohiroh:Dar al-Anshar.

Al-Kafrawi, As'ad Abdul Ghani al-Sayyid, 2002, al-Istidlal indal Ushulliyyin, Mesir: Dar al-Salam.

al-Kailani, 'Abd al-Rahmân Ibrâhîm ,2000, Qawâ'id al-Maqâsid 'inda alImâm alSyâtibi : 'Aradan wa Dirâsatan wa Tahlîlan, Damaskus: Dâr al-Fikr

al-Kamâli,'Abdullah Yahya,2000, Maqâsid al-Syarî́ah fi Dau' Fiqh alMuwâzanât, Beirut: Dâr Ibn Hazm.

al-Khafif, Ali,1996, AsbabIkhtilaf al-Fuqaha', (Kairo; Dar Dar al-Fikr al'Arabiy.

al- Qardâwi, Yûsuf, 2001, Madkhal li Dirâsat al-Syarî́ah al-Islâmiyyah, Kairo: Maktabah Wahbah.

al-Qarafi, Syihâb al-Dîn 2002, Syarh Tanqîh al-Fusûl fi Ikhtisâr al-Mahsûl fi al-Usûl, (Mesir: al-Matba'ah al-Khairiyyah, sebagaimana dikutip 
dalam 'Abd al-Azîz ibn 'Abd al-Rahmân ibn 'Ali ibn Rabî‘ah, 'Ilm Maqâsid al-Syâri', Riyad: Maktabah al-Malik Fahd al-Wataniyyah. al-Qazwini, Abi Abdillah Muhammad Ibn Yazid t.th., Juz 2, Sunan Ibn Majah, Bairut: Dar al-Fikr.

Al-Qur'an Terjemah, Mushaf al-Kamil, 2002, Editor Thoha Husein alHafidz dan Tim Editor Darussunnah, Jakarta: Darussunnah.

al-Raisûni, Ahmad dan Muhammad Jamâl Bârût, 2002, al-Ijtihâd : al-Nass, wa alWâqi', wa al-Maslahah, Damaskus: Dâr al-Fikr.

al-Raisûniy, Ahmad, t.th., Nazariyyat al-Maqâsid 'ind al-Imâm al-Syâtibi, Beirut: alMa’had al-Âlamiy li al-Fikr al-Islâmiy

al-Râzi, Muhammad ibn Abi Bakr ibn 'Abd al-Qâdir 1979, Mukhtâr alSihâh, Beirut: Dâr al-Kitâb al-Arabi.

Al-Subki, Tâj al-Dîn 'Abd. Al-Wâhhâb Ibn, 1937,Jam' al-Jawami', Mesir: Musthâfâ al-Babî al-hâlâbi.

al-Syâtibi, Abû Ishâq Ibrâhîm, t.th., Jilid I, Juz ke-2, al-Muwâfaqât fi Usûl al-Syarîah, Beirut: Dar alKutub al-Ilmiyyah.

al- Syâtibi, Abû Ishâq Ibrâhîm, t.th., Juz ke-3, al-'Itisham, Beirut:Maktabah at-Tauhid.

Al-Thufi, Abu Al-Rabi Sulaiman bin Abdul Qawi bin Abdul Karim bin Sa'id,t.th., Syarh al-Arba'în al-Nawawiyyah, lampiran dalam Mustafa Zaid, 1964, al Maslahah fi al-Tasyrî̀ al-Islâmiy wa Najm al-Dîn alTûfi, t.tp.: Dâr al-Fikr al-Arabiy.

al-Tûfi, Najm al-Dîn,1990, juz III,Syarh Mukhtashor Roudhoh tahqiq Abdullah bin Abdul Muhsin at-Tarakiy, Beirut: Mu'assasah arRisalah.

al-Tûfi, Najm al-Dîn,1993 M/1413 H, Risalah fi Riayati al-Maslahah, tahqiq Dr. Ahmad Abdul Rohim al-Sayih, Libanon : Dar al-Masdariyyah, al-Zabîdî, Muhammad Murtadâ al-Husaini, 1994, Juz ke-4, Tâj al-'Arûs min Jawâhir al-Qâmûs, Beirut: Dâr al-Fikr.

al-Zarqâ’, Mustofa Ahmad,1968, al-Fiqh al-Islâmi fi Tsaubihi al-Jadid: Madkhal al-Fiqh al-Am, Beirut: Tab'ah Tasi'ah Munqohah wa Mazidah. 
ar-Razi, Fakhruddin Muhammad bin Umar bin Hussein,1968, al-Mahsul fi Ilm Ushul Fiqh, tahqiq Dr. Jabir Fayyad al-alwani, Lebanon : Mu'assasah ar-Risalah.

as-Syafi'i, Muhammad bin Idris t.th.,ar-Risalah, tahqîq wa syarh Ahmad Muhammad Syakir Beirut : Dar al-Kitabah al-Ilmiyyah.

Asy-Syaukani, Muhammad bin Ali bin Muhammad, 1999, Irsyad al-Fuhul Ila Tahqiqi al-Haqq min 'Ilm al-Ushul, Beirut: Dar al-Kutub alIlmiyyah.

Departemen Pendidikan dan Kebudayaan, 1999, Kamus Besar Bahasa Indonesia, Jakarta: Balai Pustaka, Cetakan 10.

Fanani,Muhyar, 2009, Fiqh Madani:Kontruksi Hukum Islam di Dunia Modern, (Yogyakarta:LkiS),

Hazm, Abi Muhammad bin Ali bin Ahmad bin sa'id bin, 1979, Al-Ihkam fi Ushul al-Ahkam,tahqîq Ahmad Muhammad Syakir, taqdim Prof. Dr. Ihsan Abbas, Beirut : Dar al-Iffaq al-Jadidah.

Hissân,Husain Hâmid, 1971, Nazariyyat al-Maslahah fi al-Fiqh al-Islâmiy, Beirut:Dâr al-Nahdah al-Arabiyyah.

ibn Rabî‘ah, 'Abd al-Azîz ibn 'Abd al-Rahmân ibn 'Ali, 2002,'Ilm Maqâsid alSyâri', Riyad: Maktabah al-Malik Fahd al-Wataniyyah.

Imâm, Muhammad Kamâl al-Dîn,1998, Nazariyyat al-Fiqh fi al-Islâm: Madkhal Manhajiy, Beirut:al-Mu’assasah al-Jâmi'iyyah li al-Dirâsât wa al-Nasyr wa al Tauzî́.

Jamal Ma'mur, 2015, Rezim Gender di NU, (Yogyakarta: Pustaka Pelajar)

Khallâf, 'Abd al-Wahhâb, 1972, Masâdir al-Tasyrî̀ al-Islâmiy fîmâ lâ Nass fîh, Kuwait:Dâr al-Qalam.

Miftahul Huda, Manhaj Fikih Islam Kultural: Eksplorasi, Kritik dan Rekonstruksi, dalam JurnalAl-Manhaj : Jurnal Kajian Hukum Islam Jurusan Syariah STAIN Purwokerto, Vol. VI No. 1, Januari 2012, ISSN: $1976-6670$

Mîqâ, Abû Bakr Ismấîl Muhammad,1985, al-Ra'yu wa Atsaruhu fi Madrasat alMadînah: Dirâsah Manhajiyyah Tatbîqiyyah Tutsbitu Salâhiyyat alSyarî́ah li Kulli Zamân wa Makân, Beirut: Mu’assasatal-Risâlah, 
Mu'sâsah, Abu Abdur Rohman Sya'id, 1999, al-Muqollidun al-'Aimmah alArba'ah, Beirut: Dar Ibn Hazm.

Muhammad Bahit al-Muthi'i, 1923, Sullamul Wushul lis Syarhi Nihayat asSul, Qohiroh :Alimul Kutub.

Muslehuddin, Muhammad, 1997, Philosophy of Islamic Law and the Orientalists, New Delhi: Markazi Maktaba Islami.terj. Yuian Wahyudi Asmin, Yogyakarta: PT. Tiara Wacana Yogya.

Muslehuddin, Muhammad, t.t., Philoshopy and The Orientalist: A Comparative Study of Islamic Legal System, (Lahore: Islamic Publication, LTD)

Mustafa, Ibrâhîm dkk., al-Mu'jam al-Wasitt,t.th., Juz ke-1, Tahrân: alMaktabah al-Ilmiyyah.

Philips, Abu Ameenah Bilal, 2005, Asal-usul dan Perkembangan Fiqh Analisis Historis atas Mazhab, Doktrin dan Kontribusi, Nusamedia dan Nuansa, Bandung.

Rofiq,Ahmad,2012, Fiqh Kontekstual; dari Normatif ke Pemaknaan Sosial, Yogyakarta: Pustaka Pelajar.

Roibin, 2008, Sosiologi Hukum Islam Telaah Sosio-Historis Pemikiran Imam Syâfi'i, Malang: UIN Malang Press.

Rokhmadi, Rekonstruksi Ijtihad dalam Ilmu Usūl Fiqh, dalam Jurnal AlAhkam : Jurnal Pemikiran Hukum Islam Fakultas Syariah IAIN Walisongo Semarang, Vol. 22 No. 2, Oktober 2012, ISSN: 08454603,

Supriyadi, Ahmad, Internalisasi Hukum Islam Dalam Pranata Sosial, dalam Jurnal Yudisia: Jurnal Pemikiran Hukum dan Hukum Islam Jurusan Syariah STAIN Kudus, Edisi IV Januari-Juni 2006.

Syarifuddin, Amir. 2009, Ushul Fiqh Jilid 2.(Jakarta: Kencana).

Tamrin, Dahlan, 2007, Filsafat Hukum Islam, Malang: UIN Malang Press.

Yahya, Imam Eksekusi Hukum Mati: Tinjauan Maqāsid al-Shari'ah dan Keadilan, dalam Jurnal Al-Ahkam : Jurnal Pemikiran Hukum Islam Fakultas Syari’ah IAIN Walisongo Semarang, Vol. 23 No. 1, April 2013, ISSN: 0845-4603. 
Yasid, A, Hukum Islam Versus Positivisme Barat: Kajian Perbandingan Madzhab Jurisprudensi Perspektif Hukum Islami, dalam Jurnal AlManhaj : Jurnal Kajian Hukum Islam Jurusan Syariah STAIN Purwokerto, Vol. VI No. 1, Januari 2012, ISSN: 1976-6670

Zahrâh,Muhammad Abu,1958, Ushul Fiqh, Arab: Dar al-Fikr al-A'robiy.

Zaid, Mustafa, 1964, al-Maslahah fi al-Tasyrî̀ al-Islâmiy wa Najm al-Dîn alTûfi,: Dâr al-Fikr al-Arabiy.

Zaidan, 'Abd al-Karim,1958, al-Madkhal li Dirasah asy-Syariah alIslamiyyah, (Ttp: Muhammad 'Ali Sabih wa Auladuh)

Zakariyyâ,Abû al-Husain Ahmad ibn Fâris ibn 1981, Juz ke-3, Mu'jam Maqâyŷ̀s al-Lugah, Kairo: Maktabah al-Khânjî.

Zarkasyi,Imam, 1992, al-Bahr al-Muhit, tahrir Abdul qodir abdullah al-Ma’ani, tahqî̀ wa ta'lîq Muhammad Sulaimân al-Asyqar, Kuwait:Wazaratul Auqof Was Syu'unil Islamiyyah.

Zuhaili,Wahbah,1986, Ushul al-Figh al-Islamiy, Beirut: Dar al-Fikr. 
